\title{
Sacrifices of women and men in close relationships: the types and structure of sacrifices. The approach and avoidance motives for making sacrifices
}

\author{
Eugenia Mandal $\mathbb{1 0}$ \\ Institute of Psychology University of Silesia, Katowice, Poland
}

\section{BACKGROUND}

The aim of the study was to examine what is perceived as sacrifice in close relationships by women and by men. The goal was to find out what the structure of the sacrifices is, and whether they are related to each other. The motives of sacrifice were also examined in approach-avoidance motivation theory.

\section{PARTICIPANTS AND PROCEDURE}

The study encompassed 144 participants (93 females aged between 20 and 50) who were asked to provide casual written accounts on what constitutes sacrifice in close heterosexual relationships and the reasons why partners in those relationships would be willing to make sacrifices. The expert judge assessment method, frequency and factor analyses were used.

\section{RESULTS}

The sacrifices that were most frequently reported were those linked to an individual's professional career, sacri- fices made for family reasons and giving up one's everyday pleasures. Females more frequently make sacrifices linked to their roles within the family, while males are likely to sacrifice in changes of their lifestyle. The most common motive for sacrifice is the love motive and the least common is pressure from the outside. Women named the motive of love more frequently, while men tended to point to the willingness to improve on the quality of the relationship, their personal benefits and sense of obligation.

CONCLUSIONS

Men and women are willing to sacrifice in close relationships by trying to alter their lifestyle from that of a single person to one that prioritizes their significant others.

\section{KEY WORDS}

relational sacrifices; the sacrifice of women; the sacrifice of men; approach-avoidance sacrifice motivation

CORResponding AUthor - Prof. Eugenia Mandal, Institute of Psychology, University of Silesia, 53 Grażyńskiego Str., 40-126 Katowice, Poland, e-mail: eugenia.mandal@us.edu.pl

Authors' Contribution - A: Study design - B: Data collection - C: Statistical analysis - D: Data interpretation .

E: Manuscript preparation · F: Literature search · G: Funds collection

to Cite this ARTICLE - Mandal, E. (2020). Sacrifices of women and men in close relationships: the types and structure of sacrifices. The approach and avoidance motives for making sacrifices. Current Issues in Personality Psychology, $8(4), 317-328$.

RECEIVED 12.05.2020 • REVIEWED 07.10.2020 • ACCEPTED 09.11.2020 • PUBLISHED 29.12.2020 


\section{BACKGROUND}

\section{SACRIFICE IN CLOSE RELATIONSHIPS}

Sacrifice in a close relationship, understood as relinquishing the pursuit of one's own interests and needs for the sake of the needs and interest of the partner or of the quality of the relationship, may concern daily matters as well as more weighty issues. Sacrifice bears an adaptational value, especially in situations of conflict, when it may benefit the stability of the relationship (Van Lange et al., 1997b).

The positive consequences for the relationship include greater satisfaction and strengthening of trust and unity (Sedikides, Oliver, \& Cambel, 1994; Totenhagen, Curran, Serido, \& Butler, 2013). The negative implications mostly apply to sacrifice-making partners, who must pay a high physical and psychological price. Such a situation may cause them to feel exhausted and miserable, not willing to give up on anything anymore, which, in turn, may have a negative impact on the sense of unity and justice within a close relationship (Van Lange et al., 1997b; Impett, Gable, \& Peplau, 2005; Impett et al., 2012; Impett, Le, Kogan, Oveis, \& Keltner, 2014; Whitton, Stanley, \& Markman, 2007).

Sacrifice is linked to strong commitment, high satisfaction, and poor alternatives in close relationships (Van Lange, Agnew, Harinck, \& Steemers, 1997a). Sacrifice is correlated with attachment. While attachment that is driven by anxiety is linked to a great readiness to engage in sacrifices, attachment avoidance translates into preventing oneself from having to make sacrifices (Ruppel \& Curran, 2012).

In terms of sense of justice in a relationship, what is crucial is the perceived uneven distribution of the readiness to perform the act of sacrifice between partners. Such an asymmetry within a relationship may taint the perception of the union and ultimately lead to a breakup of the relationship (Sprecher, 2001; Frisco \& Williams, 2003). In close relationships there is compulsion in addition to sacrifice (constraint commitment). Sacrifice and constraint commitment are positively related to one another (Rhoades, Stanley, \& Markman, 2009; Stanley et al., 2017, 2019).

\section{MOTIVES OF SACRIFICE IN CLOSE RELATIONSHIPS}

Studies have shown that what is paramount for the well-being of partners in a relationship is not only the kind of sacrifice that they make but also the motivations that drive it. Sacrifice can be of an active or passive nature. Active sacrifice implies taking actions that prevent the partner who engages in sacrifices from achieving his or her goals but yield benefits for their significant others, at the same time. Passive sacrifice entails inhibiting one's own needs and desires, not allowing oneself to accomplish one's goals in order to improve the other partner's situation (Van Lange et al., 1997a).

This motivation may be considered within the framework of the approach-inhibition model (Gable, Reis, \& Elliot, 2000; Gable \& Reis, 2001; Impett et al., 2005; Impett, Javam, Le, Asyadi-Esghi, \& Kogan, 2013). The model draws on the existence of two independent motivational systems. The first one - the Behavioral Approach System (BAS) - is based on the desire to gain certain rewards, while the second one - the Behavioral Inhibition System (BIS) - is a system that allows one to avoid punishment (Carver \& White, 1994). The approach motives linked to sacrifice refer to the desire to achieve positive results (e.g. making the effort to please the partner) and the aspiration to improve the relationship (e.g. in terms of the sense of intimacy). What underlies the avoidance motives, on the other hand, is the willingness to avoid unpleasant situations (e.g. trying to fend off potential fights).

The well-being of partners seems to benefit more from sacrifices based on approach motives than on avoidance motives. For the sacrificing partner, approach motives may trigger such emotions as satisfaction, joy and happiness but also sadness, while avoidance motives are linked to anger, dissatisfaction, relief and calmness (Impett et al., 2005). The receiver of sacrifice may actually end up not appreciating the act of sacrifice, presuming that it may have been the result of his/her partner's internal motivation ("that's what he/she wanted in the first place"), or decide that the sacrifice has been prompted by external factors, e.g., circumstances and customs ("that's what everybody does") (Powell \& Van Vugt, 2003). Sacrifice based on avoidance motives usually does not increase relationship satisfaction (Mattingly \& Clark, 2012); it tends to be valued much more highly when it is "a nice surprise" - performed unexpectedly (Zoppolat, Visserman, \& Righetti, 2020).

\section{GENDER DIFFERENCES IN CLOSE RELATIONS}

The behavior of men and women in close relationships can be analyzed in the perspective of their social roles. The social roles theory (Eagly, 1997; Eagly \& Wood, 2012) states that the social roles of women and men differ. Women are more likely than men to be homemakers and primary caretakers of children and to hold caretaking jobs in the labor market. In contrast, men are more likely than women to be primary family providers and to assume full-time roles in the workplace, often ones that involve physical strength, assertiveness, or leadership skills.

In close relationships, the role of the partner and the family for the self-esteem of men and women are significant. In the theories of self-construction 
(Josephs, Markus, \& Tafarodi, 1992) it is assumed that men's and women's self-esteem arise, in part, from different sources. Self-esteem is related to successfully measuring up to culturally mandated, gender-appropriate norms - separation and independence for men and connection and interdependence for women. While women tend to be characterized by a strong interdependent self-construal, associated with placing high value on close social relations, men are high in dependent self-construal which prioritizes individual achievements (Josephs et al., 1992). It is the interdependent self-construal that is positively correlated with making sacrifices within close relationships (Day \& Impett, 2018).

Behaviors in close relationships are often considered in the exchange theory (Foa \& Foa, 1980). This theory draws attention to the role of resources held by partners in close relationships (Berg, Piner, \& Frank, 1993). Resources that are potentially exchanged between spouses are indicated: socioeconomic, affective, expressive, companionship, sex, services, and power in relationships (Safilios-Rothschild, 1976). Resources are related to power in close relationships. Two groups of resources are indicated: "the physical appearance" and "intellectual", comprising power in relationships (Sprecher, 1985).

In close relationships, the benefits and costs perceived by the partners are important. Sedikides et al. (1994) in their research on the benefits and costs associated with sacrifice in close relationships found that women more often than men name intimacy, high self-esteem and self-development as the gains that engaging in sacrifice may yield, while pointing to the loss of independence and identity as the price to pay. In contrast, men are more likely to consider sexual satisfaction a benefit and financial loss a cost of engaging in sacrifices.

\section{THE PRESENT STUDY}

In Poland, to date, no research has been done on the willingness to engage in sacrifices in close relations and the presented research was exploratory. Humanism and femininity are an important characteristic of Polish culture. Traditional family values, concern for the good of the family and good upbringing of children are highly valued. Historically, women's devotion to the family and the good of the homeland (the ideal of the Polish Mother) has always been highly appreciated (Boski, 2009). In comparison to the German, Swedish and Italian public sphere, the Polish one is more feminized and the gender polarization is greater (Boski, Chojnowska, \& Koziej, 2007). It can be assumed that in Polish close relationships there are numerous and different forms of sacrifice, and the types of the most frequent sacrifices of women and men may differ.
The purpose of the current study was to examine what is perceived as sacrifice in close relationships, distinguish different types of sacrifice and determine the structure of their interconnectedness. A question was raised: Are there sex differences in sacrifices reported by women and men?

It has been hypothesized that the most frequently occurring types of sacrifice made by women are for their children and family or are linked to giving up their career in order to support their partner's career, whereas men are more likely to sacrifice at the expense of their own personal pleasures and by changings their lifestyle (e.g., spending quality time with their partner and family and socializing less with male friends). An important issue to address herein was to identify the motives that drive sacrifice as well as their structure for both females and males in close relationships. Such discrepancies in terms of benefits and costs suggest different approach motives and avoidance motives for female and male sacrifice.

\section{PARTICIPANTS AND PROCEDURE}

The sample consisted of 144 participants (93 females, 51 males), aged between 20 and $50(M=27.77$, $S D=7.71$ ), women ranged in age from 20 to 50 years, $M=27.22$ years, $S D=7.36, t(140)=1.18, p=.243$, men ranged in age from 20 to 50 years, $M=28.82$ years, $S D=8.32$. The respondents were students enrolled in part-time courses of studies at the Silesian universities in Poland. Participants did not receive remuneration for taking part in the study. The participants were asked to provide written answers to the following questions: 1) What is sacrifice in close relationships between men and women? Provide your own examples or examples based on experiences of people you know. 2) Why do people make sacrifices in close relationships? Neither the time nor the length of the responses was limited.

The accounts provided by participants were at first subject to a qualitative and subsequently to a quantitative analysis. The purpose of the qualitative analysis was to identify types of sacrifice and different motivations linked to engaging in sacrifices. The quantitative analysis involved an analysis of frequency of particular sacrifice categories and their motives. The study used the method of expert judge assessment. The panel consisted of 4 psychologists ( 2 women and 2 men) who worked in female-male pairs, assessing to what extent the answers to the questions that the participants responded to included the distinguished categories (includes vs. does not include). The competent judges took into account all the replies of the subjects regarding both personal sacrifices and sacrifices described as observed in other close relationships known to them. 
Judges' agreement for 16 categories of types of sacrifice in 144 responses was $\kappa=0.85, t(2304)=40.72$, $p<.001$. Judges' agreement for 17 distinguished motives was $\kappa=0.90, t(2448)=44.41, p<.001$.

\section{RESULTS}

The quantitative analysis showed that the total number of acts of sacrifice that was reported by participants was $N=267$. Sixteen types of sacrifice in intimate relationships were distinguished (Figure 1). Based on the categorization of the types of sacrifice in close relationships, an analysis of the frequency of responses was conducted. The result distribution that it yielded diverged significantly from a random distribution, $\chi^{2}(15)=64.95, p<.001$. By and large, the participants referred to sacrifices linked to one's professional career, $p<.05$, sacrifices for children and family, $p<.05$, and giving up pleasure, $p<.05$, more frequently than in the case of random distribution. At the same time, sacrifices linked to the individual's values and integrity, $p<.05$, and subordination, $p<.05$, were described much less frequently.

Among female participants, the result distribution diverged significantly from a random distribution, $\chi^{2}(15)=60.12, p<.001$. More frequently than based on a random distribution, women pointed to sacrifices concerning their professional career, $p<.05$, and their children and family, $p<.05$. They were less likely to report making sacrifices in terms of their

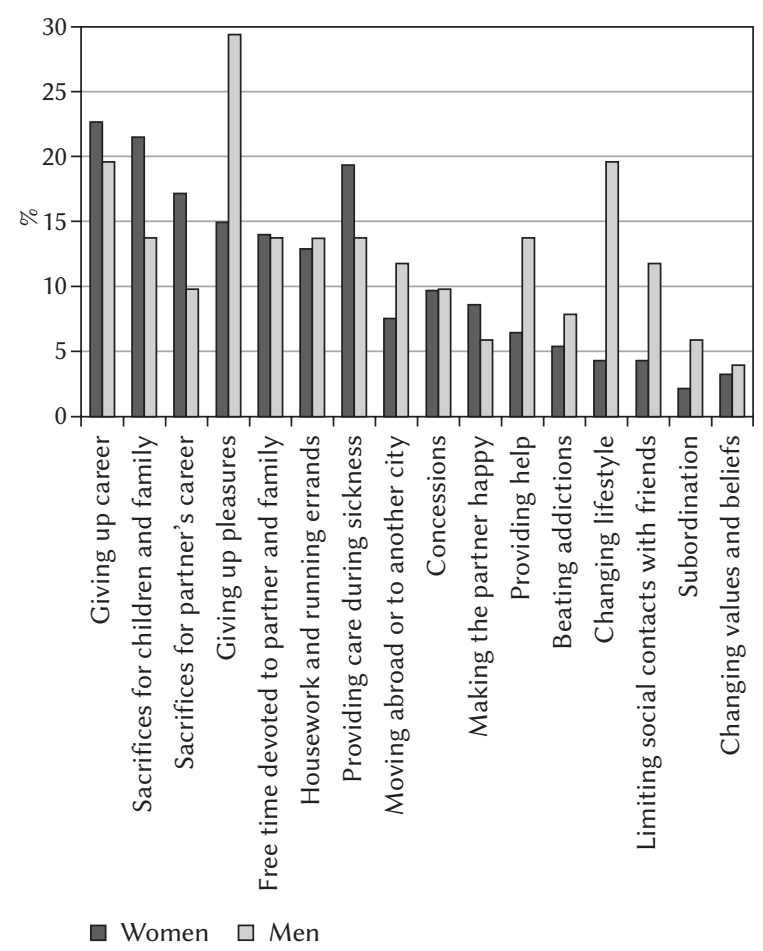

Figure 1. Types of sacrifices in close relationships reported by women and men. values and beliefs, $p<.05$, subordination, $p<.05$, and lifestyles, $p<.10$ limiting social contacts with friends and acquaintances, $p<.10$.

The analysis of frequency of occurrence of different sacrifice types for women and men showed that males $(29.41 \%)$ more often than females (14.93\%) pointed to sacrifices made at the expense of their own pleasures $(p<.05)$. Furthermore, men $(19.61 \%)$ more frequently than women $(4.30 \%)$ reported having to introduce changes to their lifestyles $(p<.01)$. Male participants $(11.76 \%)$ tended to indicate more often than women $(4.30 \%)$ sacrifices linked to limiting time for social contacts with their acquaintance (male friends) $(p<.10)$. The analysis that covered all of the investigated sacrifice types did not reveal any notable gender differences, $\chi^{2}(15)=19.48, p=.193$.

Subsequently, for both genders, a factor analysis was performed using the principal component analysis (PCA) method to determine the structure of sacrifice types. Among female participants, the eightfactor solution accounted for $69.52 \%$ of the variance. The next step was implementing Kaiser-Varimax rotation. Within the female sacrifice structure 8 factors were identified: Factor 1. Limiting spending time and friends and helping one's partner; Factor 2. Concessions and subordination; Factor 3. Housework and running errands, giving up career; Factor 4. Free time devoted to partner and family; Factor 5. Change of lifestyle; Factor 6. Moving abroad or to another city; Factor 7. Change of values; Factor 8. Giving up pleasures (Table 1).

For male participants, there was a marginal divergence of the distribution of results pertaining to types of sacrifice from a random distribution, $\chi^{2}(15)=23.69, p=.074$. Men reported giving up their pleasures slightly more frequently than based on a random distribution, $p<.05$. A factor analysis was conducted for men using the PCA method in order to determine the structure of sacrifice types. The sevenfactor solution accounted for $68.54 \%$ of the variance. Subsequently, a Kaiser-Varimax rotation was applied. Seven factors of sacrifice were distinguished for men: Factor 1. Giving up pleasures and pleasing the partner; Factor 2. Performing housework and making sacrifices for the sake of the partner's career; Factor 3. Beating addictions and limiting time spent with friends; Factor 4. Caring for a sick partner; Factor 5. Sacrificing for children and family; Factor 6. Emigrating or moving to another city; Factor 7. Giving up career and changing lifestyle (Table 2).

Analyses of the correlation between sacrifice types and age were performed. While for women, age was positively associated with engaging in housework and running errands $(r=.19)$, it was negatively correlated with subordination $(r=-.29)$ and helping the partner $(r=-.18)$. For men, age was positively correlated with the willingness to give up bad habits $(r=.23)$, emigrating or moving $(r=.20)$, while it was negatively 
Table 1

Factor loadings for sacrifices made by women

\begin{tabular}{|c|c|c|c|c|c|c|c|c|}
\hline Type of sacrifice & Factor 1 & Factor 2 & Factor 3 & Factor 4 & Factor 5 & Factor 6 & Factor 7 & Factor 8 \\
\hline Giving up career & -0.101 & -0.305 & 0.617 & & & 0.321 & & -0.117 \\
\hline $\begin{array}{l}\text { Sacrifices for children } \\
\text { and family }\end{array}$ & & 0.101 & 0.259 & & -0.196 & & & -0.722 \\
\hline $\begin{array}{l}\text { Sacrifices for } \\
\text { partner's career }\end{array}$ & & 0.141 & & 0.168 & -0.733 & 0.252 & & -0.122 \\
\hline Giving up pleasures & & & 0.219 & & -0.282 & & & 0.689 \\
\hline $\begin{array}{l}\text { Free time devoted to } \\
\text { partner and children }\end{array}$ & 0.123 & 0.155 & & -0.729 & & -0.208 & & \\
\hline $\begin{array}{l}\text { Housework and } \\
\text { running errands }\end{array}$ & -0.154 & -0.126 & -0.767 & 0.134 & & & & \\
\hline $\begin{array}{l}\text { Providing care } \\
\text { in sickness }\end{array}$ & 0.251 & 0.259 & & 0.538 & & -0.530 & 0.217 & 0.198 \\
\hline $\begin{array}{l}\text { Moving abroad or to } \\
\text { another city }\end{array}$ & 0.108 & 0.106 & & 0.186 & & 0.824 & & \\
\hline Concessions & & -0.814 & -0.226 & & & 0.115 & -0.144 & 0.167 \\
\hline $\begin{array}{l}\text { Making the partner } \\
\text { happy }\end{array}$ & 0.162 & -0.106 & -0.575 & -0.413 & & & & \\
\hline Providing help & -0.685 & 0.135 & -0.105 & & & -0.127 & -0.464 & -0.160 \\
\hline Beating addictions & -0.187 & & 0.116 & -0.534 & 0.183 & & 0.332 & 0.273 \\
\hline Changing lifestyle & & -0.101 & & & -0.828 & -0.173 & & 0.149 \\
\hline $\begin{array}{l}\text { Limiting social } \\
\text { contacts with friends }\end{array}$ & -0.883 & & & & & & 0.172 & 0.149 \\
\hline Subordination & & -0.801 & 0.129 & & & -0.145 & & \\
\hline $\begin{array}{l}\text { Changing values } \\
\text { and beliefs }\end{array}$ & & & 0.107 & & & & -0.852 & 0.162 \\
\hline Eigenvalue & 1.457 & 1.592 & 1.530 & 1.382 & 1.427 & 1.262 & 1.195 & 1.278 \\
\hline $\begin{array}{l}\% \text { of variance } \\
\text { explained }\end{array}$ & 0.091 & 0.100 & 0.096 & 0.086 & 0.089 & 0.079 & 0.075 & 0.080 \\
\hline
\end{tabular}

Note. In the table, all factor loadings lower than 0.100 are omitted. Boldface indicates highest factor loadings.

correlated with subordination $(r=-.29)$ and sacrificing for the sake of children and family (Table 3).

The motives that people pursue when making sacrifices in close relationships were divided into two groups: approach motives that aim to achieve positive outcomes and avoidance motives that help avoid negative outcomes. The total number of sacrifice motives referred to by participants of the study was $N=267$. A statistically significant prevalence of approach motives was noted compared to the occurrence of avoidance motives, $\chi^{2}(1)=136.13, p<.001$, $\varphi=0.71$. Approach motives constituted $85.77 \%$ of all reported motivation types. Gender was not significantly associated with differences in terms of the frequency of approach or avoidance motives.
In comparisons of particular motivations it was revealed that women (78.49\%) were much more likely to point to the love motive compared to men $(39.22 \%)(p<.001)$. At the same time, male participants $(17.65 \%)$ tended to report engaging in sacrifice in pursuit of a better quality of the relationship more often than females $(6.45 \%)(p<.001)$. Men pointed to motives connected with achieving the predicted positive outcomes more frequently than women (6.45\%) $(p<.05)$. Moreover, male participants $(7.84 \%)$ were more likely than women $(1.07 \%)$ to indicate the motive linked to making sacrifices out of a sense of commitment $(p<.10)$.

Subsequently, analyses of sacrifice motives were carried out, separately for male and female partici- 
Table 2

Factor loadings for types of sacrifice made by men

\begin{tabular}{|c|c|c|c|c|c|c|c|}
\hline Type of sacrifice & Factor 1 & Factor 2 & Factor 3 & Factor 4 & Factor 5 & Factor 6 & Factor 7 \\
\hline Giving up career & 0.111 & & & & -0.263 & & -0.814 \\
\hline $\begin{array}{l}\text { Sacrifices for children } \\
\text { and family }\end{array}$ & & & & 0.266 & -0.817 & 0.143 & \\
\hline Sacrifices for partner's career & -0.361 & 0.701 & & 0.202 & -0.262 & 0.103 & \\
\hline Giving up pleasures & -0.785 & & & 0.100 & & -0.182 & \\
\hline $\begin{array}{l}\text { Free time devoted to partner } \\
\text { and family }\end{array}$ & -0.344 & -0.507 & 0.316 & 0.286 & 0.255 & 0.144 & 0.132 \\
\hline $\begin{array}{l}\text { Housework and running } \\
\text { errands }\end{array}$ & & 0.772 & 0.203 & -0.163 & 0.283 & 0.146 & \\
\hline Providing care during sickness & 0.190 & & 0.172 & -0.814 & & 0.132 & \\
\hline $\begin{array}{l}\text { Moving abroad or to another } \\
\text { city }\end{array}$ & 0.288 & & -0.300 & 0.151 & 0.134 & -0.675 & \\
\hline Concessions & 0.334 & -0.258 & 0.236 & 0.435 & & 0.408 & 0.428 \\
\hline Making the partner happy & -0.680 & 0.126 & & & & 0.142 & \\
\hline Providing help & -0.420 & -0.451 & -0.169 & -0.475 & & 0.066 & 0.113 \\
\hline Beating addictions & & -0.140 & -0.746 & & 0.145 & & 0.428 \\
\hline Changing lifestyle & 0.177 & & & 0.204 & 0.537 & 0.161 & -0.632 \\
\hline $\begin{array}{l}\text { Limiting social contacts } \\
\text { with friends }\end{array}$ & & & -0.785 & 0.125 & & & \\
\hline Subordination & -0.180 & -0.220 & 0.255 & & & -0.729 & 0.100 \\
\hline Changing values and beliefs & 0.156 & & 0.174 & -0.334 & -0.513 & & -0.175 \\
\hline Eigenvalue & 1.849 & 1.724 & 1.626 & 1.501 & 1.560 & 1.343 & 1.364 \\
\hline$\%$ of variance explained & 0.116 & 0.108 & 0.102 & 0.094 & 0.098 & 0.084 & 0.085 \\
\hline
\end{tabular}

Note. In the table, all factor loadings below 0.100 are omitted. Boldface indicates highest factor loadings.

pants. The analysis performed for women indicated a considerable predominance of approach motives, $\chi^{2}(1)=91.77, p<.001$. Their distribution varied significantly from a random distribution, $\chi^{2}(11)=310.51$, $p<.001$. Women tended to report sacrifices made in pursuit of the love motive more often, $p<.001$, than out of the conviction that making sacrifices is inherent in any close relationship, $p<.01$, or with the aim of improving oneself, $p<.01$, or out of the conviction that helping the partner is the right thing to do, $p<.05$. Avoidance motives were randomly distributed, $\chi^{2}(4)=8.05, p<.10$.

In addition, factor analyses were conducted for women - one of the approach and one of the avoidance motives. The six-factor solution for approach motives accounted for $66.14 \%$ of the variance in the obtained results while the three-factor solution for avoidance motives accounted for $65.51 \%$ of the variance. In both cases, the next step was to implement Varimax (Tables 4 and 5).
The factor analysis for women yielded 6 factors: Factor 1. Enhanced well-being; Factor 2. Pursuit of improvement of relationship; Factor 3. Partner's happiness; Factor 4. Expectation for reciprocation; Factor 5. Deciding that helping is the right thing to do; Factor 6. Personal benefits. Within the structure of avoidance motives, 3 factors were determined: Factor 1. Peace and quiet; Factor 2. Fear of losing one's partner combined with external pressure; Factor 3. Sense of obligation.

Among male sacrifice motives a substantial prevalence of approach motives was revealed, $\chi^{2}(1)=44.52$, $p<.001$. Their distribution varied significantly from a random distribution, $\chi^{2}(11)=54.26, p<.001$. While men tended to report engaging in sacrifices motivated by love, $p<.01$, and the willingness to improve the relationship, $p<.10$, they were less likely to indicate that helping is the right thing to do, $p<.05$. Avoidance motives were randomly distributed, $\chi^{2}(4)=4.00$, $p=.413$. 
Table 3

Results of the analysis of the correlation between age and engaging in sacrifices

\begin{tabular}{|c|c|c|c|}
\hline Type of sacrifice & Total & Men & Women \\
\hline Giving up career & 0.05 & 0.13 & 0.01 \\
\hline Sacrifices for children and family & -0.03 & $-0.20^{*}$ & 0.06 \\
\hline Sacrifices for partner's career & 0.05 & 0.02 & 0.07 \\
\hline Free time devoted to partner and family & -0.09 & $-0.17 \dagger$ & -0.03 \\
\hline Housework and running errands & $0.11 \dagger$ & -0.03 & $0.19^{* *}$ \\
\hline Providing care in sickness & 0.00 & -0.11 & 0.06 \\
\hline Moving abroad or to another city & 0.01 & $0.20^{*}$ & $-0.13 \dagger$ \\
\hline Concessions & -0.04 & -0.04 & -0.02 \\
\hline Making the partner happy & 0.05 & 0.03 & 0.06 \\
\hline Providing help & $-0.15^{* *}$ & -0.14 & $-0.18^{* *}$ \\
\hline Beating addictions & 0.02 & $0.23^{*}$ & -0.11 \\
\hline Changing lifestyle & 0.01 & -0.09 & 0.10 \\
\hline Limiting social contacts with friends & 0.07 & $0.16 \dagger$ & -0.03 \\
\hline Giving up pleasures & -0.01 & -0.04 & -0.04 \\
\hline Changing values and beliefs & -0.02 & 0.05 & 0.01 \\
\hline Subordination & $-0.21^{* * *}$ & $-0.29^{* *}$ & $-0.15^{*}$ \\
\hline
\end{tabular}

Note. ${ }^{*} p<.05,{ }^{* *} p<.01,{ }^{* * *} p<.001, \dagger p<.10$.

Table 4

Factor loadings for approach motives for men

\begin{tabular}{|c|c|c|c|c|c|c|}
\hline Motive & Factor 1 & Factor 2 & Factor 3 & Factor 4 & Factor 5 & Factor 6 \\
\hline Love & -0.674 & 0.149 & 0.224 & 0.342 & & \\
\hline Responsibility & -0.184 & & & 0.153 & 0.403 & 0.480 \\
\hline Partner's happiness & & -0.202 & -0.839 & & & -0.109 \\
\hline Partner's significance & & 0.354 & -0.684 & 0.175 & & 0.199 \\
\hline The essence of a close relationship & & 0.789 & & -0.244 & -0.109 & \\
\hline Improvement of a close relationship & & 0.675 & & 0.181 & 0.225 & -0.161 \\
\hline The willingness to provide help & 0.544 & 0.326 & 0.171 & 0.359 & -0.352 & \\
\hline $\begin{array}{l}\text { The conviction that helping is the right } \\
\text { thing to do }\end{array}$ & & & & & -0.815 & \\
\hline Self-improvement & 0.345 & & 0.137 & -0.492 & 0.301 & 0.166 \\
\hline Expectation for reciprocation & & & & -0.832 & -0.167 & \\
\hline Personal welfare & 0.833 & & & & & \\
\hline Personal benefits & & & & & 0.163 & -0.861 \\
\hline Eigenvalue & 1.621 & 1.395 & 1.288 & 1.329 & 1.185 & 1.119 \\
\hline$\%$ of variance explained & 0.135 & 0.116 & 0.107 & 0.111 & 0.099 & 0.093 \\
\hline
\end{tabular}

Note. In the table, all factor loadings below 0.100 are omitted. Boldface indicates highest factor loadings. 
Table 5

Factor loadings for avoidance motives for women

\begin{tabular}{lccc}
\hline Motive & Factor 1 & Factor 2 & Factor 3 \\
\hline Sense of obligation & -0.106 & $\mathbf{0 . 9 4 3}$ \\
Peace and quiet & $\mathbf{0 . 6 6 6}$ & & 0.217 \\
Pressure from the outside & -0.286 & $\mathbf{- 0 . 7 7 6}$ & 0.277 \\
Fear of losing one's partner & -0.361 & $\mathbf{0 . 6 7 6}$ & 1.016 \\
Selflessness & $\mathbf{0 . 7 3 7}$ & & 0.203 \\
Eigenvalue & 1.210 & 1.059 & 0.212 \\
\hline of variance explained & 0.242 & & \\
\hline
\end{tabular}

Note. In the table, all factor loadings below 0.100 are omitted. Boldface indicates highest factor loadings.

Table 6

Factor loadings for approach motives for men

\begin{tabular}{|c|c|c|c|c|c|c|}
\hline Motive & Factor 1 & Factor 2 & Factor 3 & Factor 4 & Factor 5 & Factor 6 \\
\hline Love & & 0.074 & 0.366 & 0.114 & -0.622 & 0.478 \\
\hline Responsibility & -0.908 & 0.031 & & & & \\
\hline Partner's happiness & 0.212 & 0.206 & 0.312 & 0.264 & & -0.720 \\
\hline Partner's significance & & & -0.795 & & -0.110 & \\
\hline The essence of a close relationship & & & -0.702 & & & \\
\hline Improvement of the relationship & 0.178 & -0.249 & 0.283 & 0.437 & 0.596 & \\
\hline The willingness to provide help & -0.886 & & & & & \\
\hline $\begin{array}{l}\text { Conviction that helping is the right } \\
\text { thing to do }\end{array}$ & & -0.893 & & 0.189 & & \\
\hline Self-improvement & & -0.833 & & -0.333 & & \\
\hline Expectation for reciprocation & 0.150 & 0.153 & 0.149 & & 0.210 & 0.687 \\
\hline Personal welfare & & 0.104 & & -0.141 & 0.789 & 0.288 \\
\hline Personal benefits & 0.109 & & 0.153 & -0.924 & & \\
\hline Eigenvalue & 1.732 & 1.648 & 1.503 & 1.312 & 1.452 & 1.312 \\
\hline$\%$ of variance explained & 0.144 & 0.137 & 0.125 & 0.109 & 0.121 & 0.109 \\
\hline
\end{tabular}

Note. In the table, all factor loadings below 0.100 are omitted. Boldface indicates highest factor loadings.

Table 7

Factor loadings for avoidance motives for men

\begin{tabular}{lrc}
\hline Motive & Factor 1 & Factor 2 \\
\hline Sense of obligation & $\mathbf{- 0 . 7 1 1}$ & 0.007 \\
Peace and quiet & 0.138 & $\mathbf{0 . 7 3 4}$ \\
Pressure from the outside & $\mathbf{- 0 . 8 6 8}$ & -0.001 \\
Fear of losing one's partner & 0.147 & $\mathbf{- 0 . 7 1 5}$ \\
Selflessness & $\mathbf{- 0 . 7 1 1}$ & 0.007 \\
Eigenvalue & 1.804 & 1.051 \\
\% of variance explained & 0.361 & 0.210 \\
\hline
\end{tabular}

Note. In the table, all loadings below 0.100 are omitted. Boldface indicates highest factor loadings.
Factor analyses were performed for male participants, separately for approach motives and for avoidance motives. A six-factor solution accounted for $74.65 \%$ of the variance of the results, while a two-factor solution explained $57.10 \%$ of the variance. Subsequently, in both cases, Varimax rotation was applied. The obtained results are shown in Tables 6 and 7.

The factor analysis for male participants yielded 6 factors within the structure of approach motives in close relationships: Factor 1. Responsibility and willingness to provide help; Factor 2. Conviction that helping is the right thing to do and the idea of self-improvement; Factor 3. The essence of a close relationship; Factor 4. Personal benefits; Factor 5. Enhanced well-being and a better quality of the rela- 
tionship; Factor 6. Partner's happiness and the expectation for reciprocation. In addition, 2 factors were distinguished in the structure of avoidance motives: Factor 1. Pressure from the outside and sense of obligation; Factor 2. Peace and quiet and fear of losing one's partner.

\section{DISCUSSION}

In the current study, a number of types of sacrifice were distinguished that individuals in close relationships engage in. The respondents most often indicated such sacrifices as giving up personal pleasures, and related: changing one's lifestyle, limiting social contacts in order to be able to devote more time and attention to loved ones, getting out of bad habits, helping around the house, doing something nice for the partner, giving up pleasures or compromising. Such behaviors are to contribute to the well-being of the partner/spouse and the family, and to fend off potential conflict.

The most commonly named sacrifices were linked to one's professional career, giving up one's career and making sacrifices for the partner's career. They also included sacrifices made for children and family. Participants engaged in those types of sacrifices with the aim of enhancing the comfort and unity of the family.

The respondents also frequently mentioned being there and caring for a partner in sickness, and moving abroad with the partner or relocating to another city. Those types of sacrifices show that the participants of the study prioritize the role of the partner/ spouse, children and family, and readiness to help with housework, chores and errands. They also indicate the willingness to provide support and care, to keep the significant other company in difficult times and, ultimately, to maintain a harmonious relationship and cultivate rewarding close relations despite the problems that may arise.

The sacrifices that were listed less often were those made at the expense of one's values and beliefs or were linked to relational subordination. This may result from the fact that close relationships tend to be formed by individuals of fairly similar background (social origin, religion, nationality); hence the sense of sacrifice in terms of values and the level of subordination to the partner/spouse is a relatively rare occurrence. Furthermore, research has shown that partners are likely to avoid excessive subordination within a relationship, since what they strive for is, above all, the feeling of satisfaction, whose prerequisite seems to be each partner's autonomy (Deci \& Ryan, 2014).

The results of the study, in support of the formulated hypothesis, have shown that women were more likely to indicate sacrifices at the expense of their professional career or made for the sake of children and family, while pointing much less often to engaging in sacrifices in terms of their sets of values and beliefs, limiting their social contacts or taking the role of the subordinate partner in the relationship.

The analysis of sacrifices that women engage in indicated 8 factors. They serve to illustrate the following interconnections between various types of sacrifice. The results showed that: limiting contacts with friends was associated with providing help for one's partner; making concessions was related to subordination to one's partner/spouse; giving up one's career was associated with undertaking housework and running errands; quality time spent with the partner and family was related to beating addictions: changing one's lifestyle was associated with sacrificing for the partner's career; moving abroad or to a different city was linked to giving up one's career; changing one's set of values was correlated with kicking bad habits and helping the partner; and making sacrifices for the sake of children and family was associated with giving up one's pleasures.

This structure highlights the occurrence of interrelations of different types of sacrifices - one behavior triggers another, e.g., quitting one's job results in doing housework (and vice versa). This, in turn, points to the relationship between various forms of sacrifice and the role of a woman within a family unit and her concern about the well-being of the children and the spouse. The structure illustrates the benefits and costs associated with certain sacrifices, e.g., sacrificing for the family at the expense of one's own pleasures or giving up one's career and doing housework instead.

Consistent with the proposed hypothesis, the male participants of the study tended to report sacrificing by giving up their pleasures and changing their lifestyles more frequently than compromising their set of beliefs or giving up dominance in the relationship.

Seven factors of male sacrifice types were distinguished: giving up one's own pleasures combined with the willingness to make the partner happy; getting involved with housework and supporting the partner's career; breaking addictions combined with limiting social contacts with friends; caring for a sick partner; sacrificing one's career for the sake of children and family; emigrating or moving combined with subordination, and giving up one's career combined with changing one's lifestyle.

As with the structure of female sacrifices, the structure of sacrifices made by men shows the manner in which various forms of sacrifice intertwine. The factors distinguished in the analyses point to the sacrifices related to getting involved with the tasks traditionally reserved for females within the family and the readiness to perform housework and support women's professional careers. The structure also indicates men's readiness to introduce changes in their lifestyles (kicking bad habits, limiting social 
contacts), giving up their own pleasures and spending less time with friends in order to devote it to their partner/spouse and family and the willingness to break addictions. In addition, the structure of sacrifices made by men points to the interconnection between the benefits and the costs - gaining something in return for something else, e.g., giving up own pleasures for the sake of the partner and the relationship.

The results altogether point to the significance of gender roles, according to which, when engaging in sacrifices, women are more likely to assume roles associated with family, parenthood and providing care, while men are more inclined to adopt career-oriented roles. By and large, the structure of sacrifices made by women and men suggests that both sexes in close relations strive to initiate a change in lifestyle - from that of a single person to one that centers around the partner in a romantic relationship.

The conducted analyses indicated a correlation between the types of sacrifices and participants' age. The older the women were, the greater was their feeling of sacrifice in terms of engaging in numerous house chores, while - at the same - the less likely they were to sacrifice by adopting the role of the subordinate partner in a relationship or by helping the partner. In male participants, a positive correlation was revealed between age and the readiness to beat addictions, and emigrating or moving to another city. A negative association, by contrast, was revealed between their age and the willingness to relinquish the dominant role in the relationship and sacrificing for the sake of children and family. The results are closely tied to the dynamics of a close relationship and the changing stages of the lives of the partners involved in it.

The analysis revealed that the approach-oriented motives that are pursued with the aim of achieving a positive outcome constituted almost $90 \%$ of all motives reported by the study's participants, while the least popular motivations behind engaging in sacrifice were those concentrated on avoiding negative consequences. The results were consistent with previous research, insofar as they demonstrated the prevalence of approach-oriented motives (Impett et al., 2005).

The most frequently occurring motive of sacrifice in a close relationship was the love motive and motivations relating to it: the desire to make the partner happy or to try to show the partner how special she/ he is. Other frequently indicated motivations were: commitment and responsibility, the willingness to maintain and enhance the relationship, as well as the motive linked to improved personal well-being resulting from engaging in sacrifices for the sake of one's loved ones. Some motives were centered around the expectation for reciprocation and the benefits that making a sacrifice may produce (e.g., financial support, better mood, sex). The motives that occurred less often were linked to the sense of obligation and pressure from the outside. The motives described by participants of the study serve to validate the relationship between love and mutual support that has been observed in other studies (Noller, 1996). Among the reported motives, avoidance motives were a relatively rare occurrence. This concerns the following motivations: the fear of losing one's partner, external pressure, sense of obligation or "peace and quiet". Similar avoidance motives presented themselves in the research on daily sacrifices (Impett et al., 2005).

Within the structure of the motives that drive sacrifice, factors have been distinguished that point to an interconnection of different kinds of motivations. Among approach motives the following factors were indicated: love connected with improved well-being; striving to enhance the relationship; partner's happiness; expectation for reciprocation; the conviction that helping is the right thing to do; personal benefits. In addition, 3 factors were determined within the structure of avoidance motives: "peace and quiet", fear of losing one's partner linked to external pressure and sense of obligation.

For male participants, 6 factors were indicated within the structure of approach motives driving sacrifice: responsibility and the willingness to provide help; conviction that helping is the right thing to do and the desire to self-develop; personal benefits; improved well-being and enhanced relationship, and partner's happiness and the expectation for reciprocation. Moreover, 2 factors were distinguished within the structure of avoidance-oriented sacrifice motive: pressure from the outside and sense of obligation; "peace and quiet" connected with the fear of losing one's partner.

A comparison of motives that drive sacrifice revealed that women, more often than men, pointed to the love motive, while men were more likely to indicate the motivation that aimed to enhance the relationship. Male participants tended to more frequently list the potential benefits and sense of obligation as valid motivations behind their engaging in sacrifices. The results may reflect the sex differences in terms of agency and communion (Abele \& Wojciszke, 2007).

Men, as agency-oriented, instrumental, assertive, and striving to act individuals may be inclined to behave in a task-oriented manner - working towards raising the quality of the relationship; hence the responsibility, the conviction that helping is the right thing to do, sense of obligation, and - finally - the fact that they bear in mind the benefits that sacrifice may yield. Women, in contrast, are more communion-oriented, affectionate and emotional, and focused on interpersonal relations (Eagly, 1997). They related more to love, personal well-being and the happiness of their close ones. They also expected that their sacrifices would be reciprocated; they did not, however, indicate personal benefits as often as men did. Within the female structure of avoidance- 
oriented sacrifice motives, sense of obligation, the desire to gain peace and quiet and the fear of losing their partner/husband (connected with pressure from the outside) were revealed.

The results of the current study must be interpreted with the acknowledgement of its limitations. The research was conducted in Poland, in a country where traditional family values are highly valued. It would be interesting to compare the results obtained with research on what is understood as sacrifice in close relations in other cultural circles.

The participants of the study were relatively young - they were young or middle-aged adults, and the study did not include a comparison of the types of close relationships (e.g., marriage or cohabitation); nor did it analyze the satisfaction that those relationships provided. One might assume that those factors, like many more, may indeed influence the readiness to make sacrifices. Future research could use an analysis of more diverse close relationships between women and men, conducted on a larger scale.

\section{ACKNOWLEDGMENTS}

I would like to thank Dr. Marcin Moron for his help in carrying out some of the statistical analyses.

\section{RefEREnCES}

Abele, A. E., \& Wojciszke, B. (2007). Agency and communion from the perspective of self-versus others. Journal of Personality and Social Psychology, 93, 751-763. https://doi.org/10.1037/0022-3514.93.5.751

Berg, J. H., Piner, K. E., \& Frank, S. M. (1993). Resource theory and close relationships. In U. G. Foa, J. Converse, Jr, K. Y. Tornblom, \& E. B. Foa (Eds.), Resource theory: Explorations and applications (pp. 169-195). San Diego, CA: Academic Press.

Boski, P. (2009). Kulturowe ramy zachowań społecznych. Podręcznik psychologii międzykulturowej [Cultural frames of social behavior. A handbook of cross-cultural psychology]. Warszawa: Wydawnictwo Naukowe PWN.

Boski, P., Chojnowska, M., \& Koziej, J. (2007). Kultura i tożsamość rodzaju: Porównania polsko-włoskie i polsko-niemieckie [Culture and gender identity: Polish-Italian and Polish-German comparisons]. Studia Psychologiczne, 45, 5-20.

Carver, C. S., \& White, T. L. (1994). Behavioral inhibition, behavioral activation, and affective responses to impending reward and punishment: The BIS/ BAS Scales. Journal of Personality and Social Psychology, 67, 319-333. https://doi.org/10.1037/00223514.67.2.319

Day, L. C., \& Impett, E. A. (2018). Giving when it costs: How interdependent self-construal shapes willingness to sacrifice and satisfaction with sacrifice in romantic relationships. Journal of Social and Personal Relationships, 35, 722-742. https:// doi.org/10.1177\%2F0265407517694965

Deci, E. L., \& Ryan, R. M. (2014). Autonomy and need satisfaction in close relationships: Relationships motivation theory. In N. Weinstein (Ed.), Human motivation and interpersonal relationships (pp. 5373). Dordrecht: Springer.

Eagly, A. H. (1997). Sex differences in social behavior: Comparing social role theory and evolutionary psychology. American Psychologist, 52, 1380-1383. https://doi.org/10.1037/0003-066X.52.12.1380.b

Eagly, A. H., \& Wood, W. (2012). Social role theory. In P. A. M. Van Lange, A. W. Kruglanski, \& E. T. Higgins (Eds.), Handbook of theories of social psychology (pp. 458-476). Thousand Oaks, CA: Sage Publications Ltd.

Foa, U. G., \& Foa, E. B. (1980). Resource theory: Interpersonal behavior as exchange. In K. J. Gergen, M. S. Greenberg, \& R. H. Willis (Eds.), Social exchange: Advances in theory and research (pp. 7794). New York: Plenum Press.

Frisco, M. L., \& Williams, K. (2003). Perceived housework equity, marital happiness, and divorce in dual-earner households. Journal of Family Issues, 24, 51-73. https://doi.org/10.1177/0192513X02238520

Gable, S. L., Reis, H. T., \& Elliot, A. J. (2000). Behavioral activation and inhibition in everyday life. Journal of Personality and Social Psychology, 78, 1135-1149. https://doi.org/10.1037/0022-3514.78.6.1135

Gable, S. L., \& Reis, H. T. (2001). Appetitive and aversive social interaction. In J. Harvey \& A. Wenzel (Eds.). Close romantic relationships: Maintenance and enhancement (pp. 169-194). Mahwah, NJ: Lawrence Erlbaum Associates Publishers.

Impett, E. A., Gable, S. L., \& Peplau, L. A. (2005). Giving up and giving in: The costs and benefits of daily sacrifice in intimate relationships. Journal of Personality and Social Psychology, 89, 327-344. https://doi.org/10.1037/0022-3514.89.3.327

Impett, E. A., Javam, L., Le, B., Asyadi-Esghi, B., \& Kogan, A. (2013). The joys of genuine giving: Approach and avoidance sacrifice motivation and authenticity. Personal Relationships, 20, 740-754. https://doi.org/10.1111\%2Fpere. 12012

Impett, E. A., Kogan, A., English, T., John, O., Oveis, C., Gordon, A. M., \& Keltner, D. (2012). Suppression sours sacrifice emotional and relational costs of suppressing emotions in romantic relationships. Personality and Social Psychology Bulletin, 38, 707720. https://doi.org/10.1177\%2F0146167212437249

Impett, E. A., Le, B. M., Kogan, A., Oveis, C., \& Keltner, D. (2014). When you think your partner is holding back: The costs of perceived partner suppression during relationship sacrifice. Social Psychological and Personality Science, 5, 542-549. https://doi.org/10.1177/1948550613514455 
Josephs, R. A., Markus, H. R., \& Tafarodi, R. W. (1992). Gender and self-esteem. Journal of Personality and Social Psychology, 63, 391-402. https://doi. org/10.1037/0022-3514.63.3.391

Mattingly, B. A., \& Clark, E. M. (2012). Weakening relationships we try to preserve: Motivated sacrifice, attachment, and relationship quality. Journal of Applied Social Psychology, 42, 373-386. https:// doi.org/10.1111/j.1559-1816.2011.00893.x

Noller, P. (1996). What is this thing called love? Defining the love that supports marriage and family. Personal Relationships, 3, 97-115. https://doi. org/10.1111/j.1475-6811.1996.tb00106.x

Powell, C., \& Van Vugt, M. (2003). Genuine giving or selfish sacrifice? The role of commitment and cost level upon willingness to sacrifice. European Journal of Social Psychology, 33, 403-412. https://doi. org/10.1002/ejsp. 154

Rhoades, G. K., Stanley, S. M., \& Markman, H. J. (2009). Couples' reasons for cohabitation: Associations with individual well-being and relationship quality. Journal of Family Issues, 30, 233-258. https://doi.org/10.1177/0192513X08324388

Ruppel, E. K., \& Curran, M. A. (2012). Relational sacrifices in romantic relationships: Satisfaction and the moderating role of attachment. Journal of Social and Personal Relationships, 29, 508-529. https://doi.org/10.1177/0265407511431190

Sedikides, C., Oliver, M. B., \& Cambel, K. W. (1994). Perceived benefits and costs of romantic relationships for women and men: Implications for exchange theory. Personal Relationships, 1, 5-21. https://doi.org/10.1111/j.1475-6811.1994.tb00052.x

Sprecher, S. (2001). Equity and social exchange in dating couples: Associations with satisfaction, commitment, and stability. Journal of Marriage and Family, 63, 599-613. https://doi.org/10.1111/j.17413737.2001.00599.x

Safilios-Rothschild, C. (1976). A macro- and micro-examination of family power and love: an exchange model. Journal of Marriage and the Family, 38, 355362. https://doi.org/10.2307/350394

Sprecher, S. (1985). Sex differences in bases of power in dating. Sex Roles, 12, 449-462. https://doi. org/10.1007/BF00287608

Stanley, S. M., Rhoades, G. K., Scott, S. B., Kelmer, G., Markman, H. J., \& Fincham, F. D. (2017). Asymmetrically committed relationships. Journal of Social and Personal Relationships, 34, 1241-1259. https://doi.org/10.1177\%2F0265407516672013

Stanley, S. M., Rhoades, G. K., Scott, S. B., Kelmer, G., Markman, H. J., \& Fincham, F. D. (2019). Unequally into "US". Characteristics of individuals in asymmetrically committed relationships. Family Processes, 58, 214-231. https://doi.org/10.1111/famp. 12397

Totenhagen, C. J., Curran, M. A., Serido, J., \& Butler, E. A. (2013). Good days, bad days: Do sacrifices improve relationship quality? Journal of Social and
Personal Relationships, 30, 881-900. https://doi. org/10.1177/0265407512472475

Van Lange, P. A. M., Agnew, C. R., Harinck, F., \& Steemers, G. E. M. (1997a). From game theory to real life: How social value orientation affects willingness to sacrifice in ongoing close relationships. Journal of Personality and Social Psychology, 73, 1330-1344. https://doi.org/10.1037/0022-3514.73.6.1330

Van Lange, P. A. M., Rusbult, C. E., Drigotas, S. M., Arriaga, X. B., Witcher, B. S., \& Cox, C. L. (1997b). Willingness to sacrifice in close relationships. Journal of Personality and Social Psychology, 72, 13731395. https://doi.org/10.1037/0022-3514.72.6.1373

Whitton, S. W., Stanley, S. M., \& Markman, H. J. (2007). If I help my partner, will it hurt me? Perceptions of sacrifice in romantic relationships. Journal of Social and Clinical Psychology, 26, 64-92. https:// doi.org/10.1521/jscp.2007.26.1.64

Zoppolat, G., Visserman, M. L., \& Righetti, F. (2020). A nice surprise: Sacrifice expectations and partner appreciation in romantic relationships. Journal of Social and Personal Relationships, 37, 450-466. https://doi.org/10.1177/0265407519867145 